\title{
UPAYA PENINGKATAN KEMAMPUAN MEMBACA Al QUR'AN INDAH DENGAN METODE TILAWATI
}

\author{
Ummi Hani' Farihah \\ ummihani117@gmail.com \\ SMK Negeri 2 Balikpapan
}

\begin{abstract}
Reading the Qur'an must pay attention to the rules that have include: Tajwid Science, Gharib science, Makharijul Letters, and able to understand and pronounce long or short readings. So, in the process of learning to read the Qur'an, these rules must be studied and understood properly because if the rules are not properly understood, then the recitation of the Qur'an also becomes false. Effective teaching means teaching that students can understand perfectly. In the science of education it is often also said that proper teaching is teaching that functions in students. "Functioning" means belonging to the student, the teaching shapes and influences his person. The Tilawati method is a method of learning the Qur'an with basic techniques talqin-taqlid (mimicking) like the Prophet Muhammad mimicking the reading of the Angel Gabriel. The process of learning the Tilawati Method, always focuses on the application of tajwid science theories properly and correctly according to the command of Allah SWT which requires the recitation of the Qur'an in tartil. This research uses quantitative research. Quantitative research is a research method based on the philosophy of positivism used to examine in a particular population or sample sampling techniques are generally done randomly, data collection using research instruments, quantitative data analysis / statistics with the aim to test established hypotheses. With a descriptive format is a study by collecting field data and analyzing and drawing conclusions from the data. The success of the Qur'anic learning strategy using the Tilawati method as an effort to improve the ability to read beautifully class XI Otkp 3 learners in SMK Negeri 2 Balikpapan, indicated by an increase in the learning process, namely readiness and liveliness during the qur'an learning process, also showed an increase in the final test score score of each cycle. This can be seen from the acquisition of scores presented through observations about the learning spirit of learners with readiness and liveliness in the learning process. Based on cycles 1 and 2, there is an increase in the ability to read beautifully in the material QS Al-Maidah; 48, An-Nisa':59 and At-Taubah:105 by students of class XI Otkp 3 at SMK Negeri 2 Balikpapan. Where in cycle 1 the average value of beautiful reading skills is achieved in the range of 69.95 while in cycle 2 the average value of beautiful reading skills using the Tilawati method is in the range reaching 82.38. Where it has reached the level of completion above $73 \%$ of student who have 21 , namely with the KKM that has been determined is 73. With the increasing ability to read beautifully in the material QS Al-Maidah; 48, An-Nisa':59 and At-Taubah: 105 which has a positive impact, namely an increase in the final score above the completion value of at least KKM (73) the ability to read then learning the Qur'an using the Tilawati method is effectively applied in PAI learning.
\end{abstract}

Keywords: Ability to Read the Qur'an, Tilawati Method

Abstrak: Membaca Al-Qur'an harus memperhatikan aturan-aturan yang dimiliki antara lain: Ilmu Tajwid, ilmu Gharib, Makharijul Huruf, serta mampu memahami dan mengucapkan bacaan panjang ataupun pendek. Jadi, dalam proses pembelajaran membaca Al-Qur'an, aturan-aturan tersebut harus dipelajari dan difahami dengan sebenar-benarnya karena bila aturan-aturan tersebut tidak difahami secara benar, maka bacaan al-Qur'an juga menjadi salah. Pengajaran yang efektif artinya pengajaran yang dapat dipahami murid secara sempurna. Dalam ilmu pendidikan sering juga dikatakan bahwa pengajaran yang tepat ialah pengajaran yang befungsi pada murid. "Berfungsi" artinya menjadi milik murid, pengajaran itu membentuk dan mempengaruhi pribadinya. Metode 
Tilawati adalah metode pembelajaran Al-Qur'an dengan tehnik dasar talqin-taqlid (menirukan) seperti Nabi Muhammad menirukan bacaan Malaikat Jibril. Proses pembelajaran Metode Tilawati tersebut, selalu menitikberatkan pada penerapan teori-teori ilmu tajwid secara baik dan benar sesuai perintah Allah SWT yang mewajibkan pembacaan Al-Qur'an secara tartil. Penelitian ini menggunakan Penelitian kuantitatif. Penelitian kuantitatif adalah metode penelitian yang berlandaskan pada filsafat positivisme digunakan untuk meneliti pada populasi atau sampel tertentu teknik pengambilan sampel pada umumnya dilakukan secara random, pengumpulan data menggunakan instrument penelitian, analisis data bersifat kuantitatif/statistic dengan tujuan untuk menguji hipotesis yang telah ditetapkan. Dengan format deskriptif yaitu suatu penelitian dengan mengumpulkan data lapangan dan menganalisa serta menarik kesimpulan dari data tersebut. keberhasilan strategi pembelajaran Al-qur'an menggunakan metode Tilawati sebagai upaya untuk meningkatkan kemampuan membaca indah peserta didik kelas XI Otkp 3 di SMK Negeri 2 Balikpapan, ditunjukkan dengan adanya perubahan peningkatan dalam proses pembelajaran yaitu kesiapan dan keaktifan pada saat proses pembelajaran Al-qur'an, juga ditunjukkan adanya peningkatan nilai skor tes akhir dari masing-masing siklus. Hal ini dapat dilihat dari perolehan skor yang dipresentasikan melalui pengamatan tentang semangat belajar peserta didik dengan kesiapan dan keaktifan dalam proses pembelajaran. Berdasarkan siklus 1 dan 2, terdapat peningkatan kemampuan membaca indah pada materi QS Al-Maidah;48, An-Nisa':59 dan At-Taubah:105 oleh siswa kelas XI Otkp 3 di SMK Negeri 2 Balikpapan. Dimana pada siklus 1 rata-rata nilai keterampilan membaca indah dicapai pada kisaran 69,95 sedangkan pada siklus 2 rata-rata nilai keterampilan membaca indah menggunakan metode Tilawati berada pada kisaran mencapai 82,38. Dimana telah mencapai pada tingkat ketuntasan diatas $73 \%$ dari siswa yang berjmlah 21 yaitu dengan KKM yang telah ditentukan adalah 73. Dengan meningkatnya kemampuan membaca indah pada materi QS Al-Maidah;48, An-Nisa':59 dan At-Taubah:105 yang mempunyai dampak positif yaitu peningkatan nilai skor akhir diatas nilai ketuntasan minimal KKM (73) kemampuan membaca maka pembelajaran Al-qur'an menggunakan metode Tilawati berjalan efektif diterapkan dalam pembelajaran PAI

Kata Kunci: Kemampuan Membaca Al Qur'an, Metode Tilawati

\section{Pendahuluan}

Pendidikan Agama merupakan salah satu dari tiga subyek pelajaran yang harus dimasukkan dalam kurikulum setiap lembaga pendidikan formal di Indonesia. Hal ini dikarenakan kehidupan beragama merupakan salah satu dimensi kehidupan yang diharapkan dapat terwujud secara terpadu dengan dimensi kehidupan lain pada setiap individu warga negara. Pasal 39 ayat 2 Undang-undang nomor 2 Tahun 1989, pendidikan Agama merupakan usaha untuk memperkuat iman dan ketakwaan terhadap Tuhan Yang Maha Esa sesuai dengan agama yang dianut oleh peserta didik yang bersangkutan dengan mempertimbangkan tuntunan untuk menghormati agama lain dalam hubungan kerukunan antar umat beragama dalam masyarakat untuk mewujudkan persatuan nasional ${ }^{1}$

Pendidikan Agama Islam adalah usaha untuk memperkuat iman dan ketakwaan terhadap Tuhan Yang Maha Esa, sesuai dengan ajaran Islam, bersikap inklusif, rasional dan filosofis dalam rangka menghormati orang lain dalam hubungan kerukunan dan kerjasama antar umat beragama dalam masyarakat untuk mewujudkan persatuan $\mathrm{Nasional}^{2}$

Pendidikan Agama Islam merupakan rumpun mata pelajaran yang dikembangkan dari ajaran-ajaran pokok (dasar) yang terdapat dalam agama Islam. Ditinjau dari segi isinya, Pendidikan Agama Islam merupakan mata pelajaran pokok yang menjadi salah satu komponen, dan tidak dapat dipisahkan dari rumpun mata pelajaran yang bertujuan, mengembangkan moral dan kepribadian siswa. Dalam mata pelajaran Pendidikan Agama Islam ini juga mengajarkan agar siswa dapat membaca Al-Qur'an dengan tartil dan benar berdasarkan ilmu tajwid.

\footnotetext{
${ }^{1}$ Fakultas Tarbiyah IAIN Walisongo. 1999. Metodologi Pengajaran Agama. Yogyakarta: Pustaka Pelajar Offset 11

2 Aminudin.2006. Prosedur Penelitian Suatu Pendekatan Praktek. Jakarta: PT Asdi Mahasatya, 1
} 
Menurut Kamus Besar Bahasa Indonesia, membaca diartikan sebagai melihat serta memahami isi dari apa yang tertulis (dengan melisankan atau hanya dalam hati) ${ }^{3}$ Sedangkan membaca Al-Qur'an adalah melihat serta memahami isi dari apa yang tertulis dalam Al-Qur'an dengan tartil dan benar berdasarkan ilmu tajwid.

Al-Qur'an dari segi bahasa, berasal dari kata qara'a - yaqra'u - qira'atan qur'anan, yang berarti sesuatu yang dibaca atau bacaan. Dari segi Istilah, Al-Qur'an adalah kalamullah yang diturunkan kepada Nabi Muhammad saw, dalam bahasa Arab, yang sampai kepada kita secara mutawattir, ditulis dalam mushaf, dimulai dengan surah Al-Fatihah dan diakhiri dengan surah AnNaas, membacanya berfungsi sebagai ibadah, sebagai mukjizat Nabi Muhammad saw. Dan sebagai Hidayah atau petunjuk bagi umat manusia ${ }^{4}$

Al-Qur'an merupakan wahyu, kalam atau firman Allah yang mengandung ajaran untuk dijadikan pedoman dan tuntunan dalam tata nilai kehidupan manusia dan seluruh alam, karena pada dasarnya Al-Qur'an diturunkan sebagai rahmat bagi semesta alam. Ajarannya berlaku sepanjang masa, sejak diturunkan hingga hari kiamat. Kebenaran yang terkandung didalamnya tidak dapat diragukan lagi, karena Allah sendiri yang menjaganya. Allah berfirman didalam Al-Qur'an surat alHijr ayat 9 :

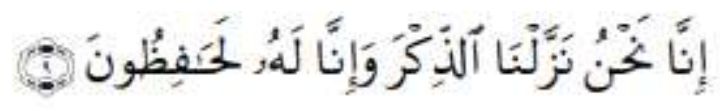

Artinya : "Sesungguhnya Kami-lah yang menurunkan Al Quran, dan sesungguhnya Kami benar-benar memeliharanya”. (Q.S Al-Hijr: 9)

Membaca Al-Qur'an harus memperhatikan aturan-aturan yang dimiliki antara lain: Ilmu Tajwid, ilmu Gharib, Makharijul Huruf, serta mampu memahami dan mengucapkan bacaan panjang ataupun pendek. Jadi, dalam proses pembelajaran membaca Al-Qur'an, aturan-aturan tersebut harus dipelajari dan difahami dengan sebenar-benarnya karena bila aturan-aturan tersebut tidak difahami secara benar, maka bacaan al-Qur'an juga menjadi salah.

Selain itu yang harus diperhatikan dalam membaca Al-Qur'an yaitu membaca Al-Qur'an wajib menggunakan tartil. Sebagaimana perintah Allah SWT dalam surat Al-Muzammil ayat 4 :

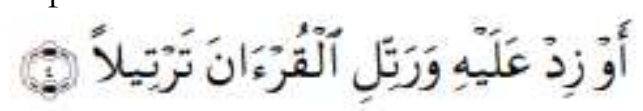

Artinya : "Atau lebih dari seperdua itu. Dan bacalah Al Quran itu dengan perlahan-lahan". (Q.S Al-Muzammil: 4)

Pengajaran yang efektif artinya pengajaran yang dapat dipahami murid secara sempurna. Dalam ilmu pendidikan sering juga dikatakan bahwa pengajaran yang tepat ialah pengajaran yang befungsi pada murid. "Berfungsi" artinya menjadi milik murid, pengajaran itu membentuk dan mempengaruhi pribadinya ${ }^{5}$

Metode Tilawati adalah metode pembelajaran Al-Qur'an dengan tehnik dasar talqin-taqlid (menirukan) seperti Nabi Muhammad menirukan bacaan Malaikat Jibril. Proses pembelajaran Metode Tilawati tersebut, selalu menitikberatkan pada penerapan teori-teori ilmu tajwid secara baik dan benar sesuai perintah Allah SW'T yang mewajibkan pembacaan Al-Qur'an secara tartil.

Sejauh ini, hasil pembelajaran Pendidikan Agama Islam materi membaca Al-Qur'an di SMK belum bisa tercapai secara maksimal seperti yang diharapkan. dengan KKM 75 dari 36 siswa,

\footnotetext{
${ }^{3}$ Kamus Besar Bahasa Indonesia (KBBI). 2008. Jakarta: Pusat Bahasa.113

${ }^{4}$ Buku Paket SMA/SMK, 2015: 47

${ }^{5}$ Ahmad Tafsir.(2008). Ilmu Pendidikan Islam dalam persefektif islam. Bandung :Remaja Rosda Karya, 9
} 
yang lulus hanya 13 siswa atau dalam persen sebesar 33\% dan yang tidak lulus ada 23 siswa atau dalam persen sebesar 67\% dengan rata-rata 67.60.

Peneliti menemukan beberapa problematika rendahnya hasil belajar Pendidikan Agama Islam materi membaca Al-Qur'an pada siswa kelas XI SMK Negeri 2 Balikpapan, diantaranya adalah guru yang kurang terampil menerapkan berbagai macam metode mengajar yang sesuai dengan materi membaca Al-Qur'an dan keterbatasan sarana dan prasarana sekolah yang mendukung pembelajaran.

Sekarang banyak ditemui adanya metode pembelajaran membaca Al-Qur'an yang lebih menuntut siswa berperan lebih aktif dan lebih siap untuk menerima pembelajaran membaca AlQur'an diantaranya adalah metode Tilawati. Pemilihan metode pembelajaran membaca Al-Qur'an dengan menggunakan metode Tilawati dirasa sesuai untuk membantu siswa meningkatkan hasil belajar membaca Al-Qur'an secara tartil dan bernada Indah.

Berdasarkan hasil pengamatan tersebut maka peneliti bermaksud mengadakan Penelitian pada siswa kelas XI Otkp 3 dengan memberi judul penelitian : Peningkatan kemampuan membaca Al-qur'an dengan metode Irama Tilawati pada K.D 3.1 (Membaca Indah QS An-Nisa'/4:59) di kelas XI Otkp 3 SMK Negeri 2 Balikpapan Tahun Pelajaran 2020/2021

\section{Kajian Teori}

Pengertian Hasil Belajar

Hasil belajar merupakan perubahan perilaku yang diperoleh siswa setelah mengalami aktifitas belajar ${ }^{6}$ Menurut Bloom, hasil belajar adalah perubahan-perubahan yang terjadi pada diri siswa baik yang menyangkut aspek kognitif, afektif dan psikomotor sebagai hasil dari kegiatan belajar ${ }^{7}$ Secara sederhana, hasil belajar adalah kemampuan yang diperoleh anak setelah melalui kegiatan pembelajaran. Anak yang berhasil dalam belajar adalah yang berhasil mencapai tujuan-tujuan pembelajaran.

Pendidikan Agama Islam adalah upaya sadar dan terencana dalam menyiapkan peserta didik untuk mengenal, memahami, menghayati, hingga mengimani, bertakwa dan berakhlak mulia dalam mengamalkan ajaran agama Islam dari sumber utamanya kitab suci Al-Qur'an dan Al-Hadis, melalui kegiatan bimbingan, pengajaran, latihan, serta penggunaan pengalaman ${ }^{8}$

Pendidikan Agama Islam adalah upaya sadar dan terencana dalam menyiapkan peserta didik untuk mengenal, memahami, menghayati, hingga mengimani, bertakwa dan berakhlak mulia dalam mengamalkan ajaran agama Islam dari sumber utamanya kitab suci Al-Qur'an dan Al-Hadis, melalui kegiatan bimbingan, pengajaran, latihan, serta penggunaan pengalaman ${ }^{9}$

Membaca diartikan sebagai melihat serta memahami isi dari apa yang tertulis (dengan melisankan atau hanya dalam hati) ${ }^{10} \mathrm{Al}$-Qur'an adalah kalam Allah/wahyu Illahi sebagai mu'jizat yang diturunkan dengan perantaraan Malaikat Jibril yang tertulis dalam mushaf-mushaf yang dipindahkan kepada kita jengan jan mutawatir yang dianggap ibadah dengan membacanya dan dihukumi kafir dengan mengingkarinya yang dimulai dengan surat al-Fatihah dan diakhiri dengan surat an-Naas ${ }^{11}$. Jadi membaca Al-Qur'an

\footnotetext{
6 Saefullah. 2012. Psikologi Perkembangan dan Pendidikan. Bandung: Pustaka Setia, 204

${ }^{7}$ Agus Suprijono. 2009. Cooperative Learning: Teori dan Aplikasi PAIKEM, Jakarta : Grasindo.5

8 Abdul, Majid. 2012. Perencanaan Pembelajaran. Bandung: Rosda Karya, 11

${ }^{9}$ Ibid

${ }^{10}$ KBBI, 2008: 113

${ }^{11}$ Munjahid. 2007. Strategi Menghafal Al-Qur'an 10 Bulan Khatam. Yogyakarta: IDEA Press: 26
}

72 Ummi Hani' Farihah-UPAYA PENINGKATAN KEMAMPUAN MEMBACA Al QUR'AN INDAH DENGAN METODE TILAWATI 
yang dimaksud peneliti adalah memahami isi dari apa yang tertulis dalam Al-Qur'an secara fasih dan sesuai dengan ilmu tajwid.

Membaca Al-Qur'an (tilawatul/qira'atul Qur'an) adalah salah satu ibadah yang banyak mengandung keutamaan. Ia adalah pintu gerbang meraih petunjuk-petunjuk yang terkandung di dalam Al-Qur'an. Siapa pun yang menginginkan petunjuk dari Allah pasti akan menjadikan tilawatul Qur'an sebagai ibadah unggulannya. Siang dan malam ia tidak akan menjauh dari AlQur'an. Bibir kering dan kerongkongan serak bukan halangan untuk mendapatkan keutamaan kitab suci itu.

Untuk memompa semangat belajar Al-Qur'an, amat penting mengetahui keutamaan membaca dan mengajarkannya. Diantara keutamaan-keutamaan tersebut adalah sesuai dengan isi kandungan hadis-hadis berikut ini.

a. Hadis dari Utsman bin Affan r.a., Rasulullah saw. bersabda,

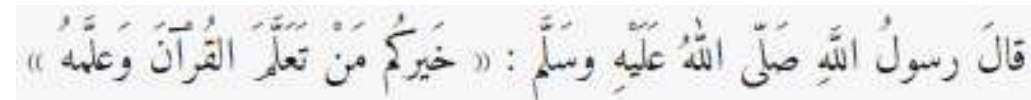

Artinya: "Dari Rasulullah S.A.W bersabda: Sebaik-baik kalian adalah yang mempelajari al-Qur'an dan mengajarkannya." (HR Bukhari)

Hadis tersebut menegaskan bahwa orang yang belajar al-Qur'an, lalu setelah bisa, mengajarkannya kepada orang lain, adalah orang terbaik yang akan mendapatkan banyak kebaikan, baik di dunia maupun di akhirat.

b. Bacaan Al-Qur'an akan menjadi syafaat bagi pembacanya, seperti hadis dari Abu Umamah, Rasulullah saw. bersabda,

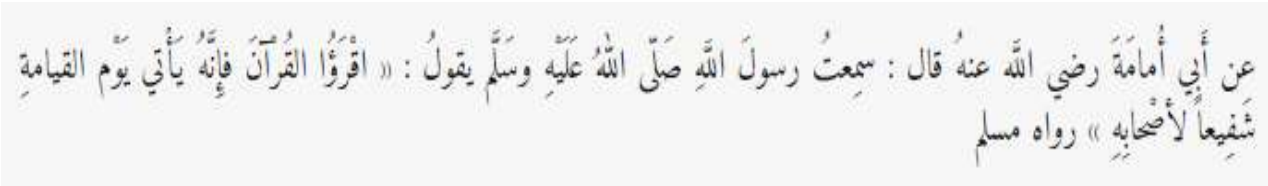

Artinya: "Aku mendengar Rasulullah S.A.W telah berkata ; Bacalah al-Qur'an karena ia akan datang pada hari Kiamat sebagai pemberi syafa'at kepada para ahlinya." (HR. Muslim)

c. Para pembaca Al-Qur'an akan mendapatkan pahala yang berlipat, Rasulullah saw. bersabda,

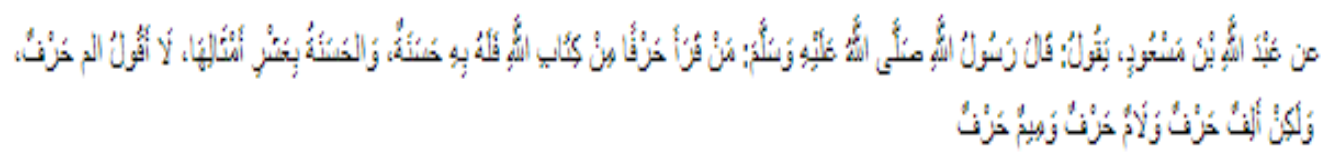

Artinya: "Rasulullah S.A.W bersabda; Barang siapa yang membaca satu huruf dari Kitab Allah, ia mendapat satu kebaikan dan tiap kebaikan mendapat pahala lipat sepuluh. Aku tidak berkata alif lam mim itu satu huruf, tetapi alif satu huruf, lam satu huruf, dan mim satu huruf.” (HR Turmudzi)

Untuk mempelajari Al-Qur'an, langkah pertama yang harus dilakukan adalah belajar membacanya. Jika seseorang sudah bisa membaca tulisan, maka setelah itu orang tersebut dapat menulisnya, sampai orang tersebut mengetahui maksud dari apa yang telah dibacanya.

Dasar membaca dalam Al-Qur'an sudah diterangkan bahwasannya membaca adalah langkah untuk memahami sesuatu. membaca adalah suatu langkah awal dimana seseorang mendapat ilmu pengetahuan dari pembacaan kemudian timbul suatu pemahaman dan terciptalah ilmu pengetahuan. Akan tetapi, belajar membaca Al-Qur'an 
dibutuhkan usaha dan kesabaran yang tinggi untuk dapat membacanya dengan baik dan benar sesuai dengan kaidah tajwid. Bahkan kita disyaratkan membaca Al-Qur'an dengan tartil.

Tartil adalah membaca Al-Qur'an dengan perlahan-lahan dan tidak terburu-buru dengan bacaan baik dan benar sesuai dengan makhraj dan sifat-sifatnya sebagaimana dijelaskan di beberapa buku tajwid. Cara membacaa Al-Qur'an tersebut wajib menggunakan ilmu Tajwid dengan menyesuaikan bacaannya (Tahqiq, Tartil, Tadwir atau Hadr). Tajwid secara bahasa berarti 'memperbagus'. Sedangkan secara istilah berarti melafalkan hurufhuruf dalam Al-Qur'an dengan benar dan sesuai ketentuan makharijul huruf (tempat keluarnya huruf) serta melembutkan pengucapannya, tidak berlebihan, kasar, tergesagesa, atau dipaksakan. Faedah Ilmu Tajwid adalah : supaya lisan kita terjaga dari kesalahan di dalam membaca Kitabullah al-Qur'an.

Seiring perkembangan zaman, banyak sekali metode-metode pembelajaran membaca alQur'an terbaru yang ditujukan agar anak dapat belajar dengan mudah dan riang.

Sekarang, banyak metode belajar membaca al-Qur'an yang baru, semuanya praktis dan lebih gampang. Kita yang belum lancar atau belum mampu membaca AlQur'an sama sekali, bisa memakai metode baru itu. Banyak sekali lembaga pendidikan Al-Qur'an menggunakan metode yang baru guna untuk menunjang keberhasilan peserta didiknya dalam hal membaca Al-Qur'an. Beragam pula cara yang dipakai dalam suatu metode, mulai dari cara membaca cepat atau model baca cepat, membaca dengan menyelipkan lagu-lagu tilawah, atau membaca dengan melafalkan huruf dengan suara keras.

Salah satu metode yang berkembang saat ini adalah metode Tilawati, Metode tilawati dalam pembelajaran Al-Qur'an yaitu suatu metode atau cara belajar membaca Al-Qur an dengan ciri khas menggunakan lagu rost dan menggunakan pendekatan yang seimbang antara pembiasaan melalui klasikal dan kebenaran membaca melalui individual dengan tehnik baca simak. Metode ini aplikasi pembelajarannya dengan lagu rast. Rast adalah Allegro yaitu gerak ringan dan cepat.

Metode Tilawati merupakan metode belajar membaca Al-Qur'an yang menggunakan nada-nada tilawah dengan pendekatan yang seimbang antara pembiasaan melalui klasikal dan kebenaran membaca melalui individual dengan teknik baca simak. Dengan penerapan lagu dalam bacaan al-Qur'an siswa akan lebih senang dalam proses pembelajaran dan gemar membaca Al-Qur'an sehingga berdampak pada hasil belajar siswa. Dan diantara lembaga-lembaga pendidikan al-Qur'an yang menggunakan metode Tilawati adalah YSPI SD Kyai Ibrahim Surabaya.

\section{Sejarah Metode Tilawati}

Metode Tilawati ini timbul karena keprihatinan para aktifis yang sudah lama berkecimpung di dunia TPQ/ TPA merasakan masih banyak kalangan umat Islam yang belum bisa membaca dan menulis Al-Qur'an. Dan beraneka ragam metode pembalajaran baca Al-Qur'an yang berkembang sehingga berimbas adanya gap dari masing-masing lembaga penganut beraneka ragam metode tersebut. Selain daripada itu lahirnya metode metode tilawati ini disebabkan antara lain: 1). Bergesernya peran orang tua terhadap anak (kurang efektif) 2). Terhapusnya pelajaran pegon (arab gundul) di sekolah. 3). 
Perkembangan zaman yang kurang kondusif bagi pendidikan Al-Qur'an. 4). Sebagian guru kehilangan cara efektif untuk mengajar Al-Qur'an sehingga mutu pendidikan kian merosot. 5). Penggunaan sebuah metode yang tidak maksimal dan total sehingga berjalan setengahsetengah . 6). Fenomena yang terjadi anak biasanya khatam dari sebuah metode pembelajaran Al-Qur'an terlalu lama. 7). Keadaan manajemen TPQ/TPA banyak yang semrawut, hanya sekedar mengajarkan Al-Qur'an sebisanya. 8). Banyaknya staf pengajar alQur'an yang tidak berkualitas dalam bacaannya.

Metode Tilawati disusun pada tahun 2002 oleh Tim terdiri dari Drs.H. Hasan Sadzili, Drs H. Ali Muaffa dkk. Kemudian dikembangkan oleh Pesantren Virtual Nurul Falah Surabaya. Metode Tilawati dikembangkan untuk menjawab permasalahan yang berkembang di sekolah, antara lain: 1). Mutu Pendidikan Kualitas santri lulusan TK/TP AlQur'an belum sesuai dengan target. 2). Metode pembelajaran masih belum menciptakan suasana belajar yang kondusif. Sehingga proses belajar tidak efektif. 3). Pendanaan Tidak adanya keseimbangan keuangan antara pemasukan dan pengeluaran. 4). Waktu pendidikan Waktu pendidikan masih terlalu lama sehingga banyak santri drop out sebelum khatam AlQur'an. 5). Kelas TQA Pasca TPA TQA belum bisa terlaksana.

Dalam toeri pendidikan dikatakan bahwa media pengajaran menyumbangkan keberhasilan $20 \%$, guru menyumbangkan $30 \%$, dan manajemen menyumbangkan keberhasilan 50 \%. Dengan landasan teori ini pula Lembaga Pengelola Al-Qur'an Yayasan pesantren Virtual Nurul Falah, yang dalam hal disusun oleh para praktisi dan motor penggerak TPQ Indonesia (Drs. Hasan Sadzilli, Drs. HM. Tohir Al Aly, M,Ag, KH. Masrur Mashud, dan Drs. H. Ali Muaffa) mengembangkan metode mengajar Al-Qur'an dengan memadukan 3 konsep keberhasilan tersebut.

Berdasarkan penjelasan di atas maka jelaslah bahwa yang paling banyak menyumbangkan keberhasilan dalam pendidikan pembelajaran Al-Qur'an adalah manajemen pendidikan yang terkelola dengan baik sebanyak 50\%, sedangkan guru sebagai pelaksana pendidikan dan pengajaran termasuk dalam penggunaan metode yang diterapkan tingkat keberhasilannya mencapai 30\%.

Sesuai dengan latar belakang sejarah tilawati, maka metode tilawati mempunyai tujuan umum sebagai berikut: 1). Ikut andil dalam mencerdaskan anak bangsa supaya bisa membaca Al- Qur'an dengan lancar dan benar . 2). Nasyrul ilmi (menyebarluaskan ilmu) khususnya Ilmu Al Qur'an. 3). Memasyarakatkan Al-Qur'an dengan metode tilawati. 4). Membetulkan yang salah dan menyempurnakan yang kurang. 5). Mengajak mendarus dan musyafahah Al-Qur'an sampai khatam.

Adapun tujuan khusus pembelajaran Al-Qur'an dengan metode tilawati ini adalah: 1). Santri mampu membaca Al-Qur'an dengan tartil (lagu rosy) 2). Santri mampu membenarkan bacaan Al-Qur'an yang salah 3). Santri mampu belajar tuntas (tuntas belajar secara individu $70 \%$ dan tuntas secara kelompok $80 \%$ 4). Dapat khatam jilid maximal 24 bulan (2 tahun) 5). Dapat khatam 30 Juz al-Qur'an maximal 18 bulan (1,5 tahun)

Adapun prinsip utama yang dipegang oleh pengajar, dalam penggunaan metode tilawati adalah: 1). Disampaikan dengan praktis (pendekatan praktis bukan teoritis) 2). Menggunakan lagu/ irama rost 3). Menggunakan pendekatan klasikal dan individual (baca simak) secara seimbang. Sedangkan dalam manajemennya, metode tilawati berpatokan pada prinsip-prinsip sebagai berikut: 1). Kualitas yang diarahkan pada pengguna 2). Perbaikan berkelanjutan (continuous improvement) 3). Perbaikan sedikit demi sedikit ( step by step 
improvement ) 4). Partisipasi total 5). Perubahan kultur ( change of culture ) 6). Cepattanggap 7). Pengukuran 8). Manajemen berbasis fakta 9). Pengembangan kemitraan

\section{Metode}

Penelitian ini menggunakan Penelitian kuantitatif. Penelitian kuantitatif adalah metode penelitian yang berlandaskan pada filsafat positivisme digunakan untuk meneliti pada populasi atau sampel tertentu teknik pengambilan sampel pada umumnya dilakukan secara random, pengumpulan data menggunakan instrument penelitian, analisis data bersifat kuantitatif/statistic dengan tujuan untuk menguji hipotesis yang telah ditetapkan ${ }^{12}$. Dengan format deskriptif yaitu suatu penelitian dengan mengumpulkan data lapangan dan menganalisa serta menarik kesimpulan dari data tersebut ${ }^{13}$

Variabel adalah simbol yang nilainya dapat bervariasi, yaitu angkanya dapat berbeda-beda dari satu subjek kesubjek lain atau dari satu objek keobjek lain ${ }^{14}$. Adapun variabel penelitian yang akan digunakan pada penelitian ini adalah kemampuan membaca indah qur'an Surah An-Nisa' : 59

Tempat penelitian tindakan ini, penulis lakukan di SMKN 2 Balikpapan tahun pelajaran 20202021 semester ganjil. Menurut data yang peneliti kumpulkan sebagai tindakan observasi pendahuluan tergambar bahwa populasi dari siswa SMKN 2 Balikpapan berjumlah 1378 yang terdiri dari:

a) Kelas $\mathrm{X}$ berjumlah 467

b) Kelas XI berjumlah 412

c) Kelas XII berjumlah 499 .

Data di atas peneliti dapatkan dari laporan bulanan sekolah per tanggal 30 Juni 2019. Dari populasi di atas, para siswa terdistribusi menjadi 39 kelas dengan program keahlian terdiri dari:

a) Keuangan dan Perbankan (Akuntansi dan Keuangan Lembaga/ AKL - Perbankan dan Keuangan Mikro/ PKM)

b) Otomatisasi Tata Kelola Perkantoran (OTKP)

c) Bisnis Daring dan Pemasaran (BDP)

d) Tehnik informatika (Tehnik Komputer dan Jaringan/ TKJ - Rekayasa Perangkat Lunak/ RPL - Multimedia/ MM)

Penelitian ini menggunakan sampel purposiv dari kelas XI OTKP 3. Hal demikian karena peneliti sekaligus pendidik di SMKN 2 Balikpapan mendapat jam mengajar di kelas tersebut. Temuan masalah kemampuan membaca Indah pertama kali penulis dapati di kelas tersebut.

Peneliti mendapat tugas mengajar sebanyak 8 kelas yang masing-masing bila menggunakan tatap muka satu pekan setiap kelas menerima layanan pendidikan sebanyak 3 jam pelajaran (@ 45 menit). Delapan kelas tersebut terdiri dari:

1) XII Akuntansi dan Keuangan Lembaga (XII AKL 1)

2) XII Akuntansi dan Keuangan Lembaga (XII AKL 2)

3) XII Akuntansi dan Keuangan Lembaga (XII AKL 3)

\footnotetext{
12 Sugiono, 2010:13-14

${ }^{13}$ Suharsimi Arikunto, 2006. Penelitian Tindakan Kelas. Jakarta: PT Bumi Aksara:106

14 Azwar, 2009
} 
4) XII Teknik Komputer Jaringan (XII TKJ 1)

5) XI Teknik Komputer Jaringan (XI TKJ)

6) XI Akuntansi dan Keuangan Lembaga (XI AKL 3)

7) XI Otomatisasi Tata Kelola Perkantoran (OTKP 3)

8) XI Perbankan dan Keuangan Mikro (PKM)

Kelas XI menjadi pilihan yang tepat untuk dijadikan sampel penelitian ini karena kemampuan membaca Indah siswa dapat dibimbing dari level yang sederhana. Jumlah peserta didik yang ada di kelas XI OTKP 3 Tahun Pelajaran 2020/2021 berjumlah 34 orang. Terdiri dari 31 Muslim dan 3 orang non muslim. Dari 31 muslim, 2 siswa laki-laki, 29 siswa wanita. Dengan demikian jumlah siswa yang akan mendapat bimbingan dan tindakan kelas mengarah perbaikan kemampuan kognitif sebanyak 31 siswa. Bila penelitian tindakan kelas ini berhasil maka pola tindakan yang sama akan sangat berguna digunakan untuk kelas lainnya, khususnya kelas lanjutan setelah XI OTKP, ada XI PKM, XI AKL 3 dan XI TKJ.

Teknik pengumpulan data dalam penelitian ini ada beberapa teknik pengumpulan data yang digunakan penulis, antara lain:

1. Tes adalah serentetan pertanyaan atau latihan serta alat lain yang digunakan untuk keterampilan, penggetahuan intelegensi, kemampuan atau bakat yang dimiliki oleh individu atau kelompok ${ }^{15}$. Tes yang digunakan penulis adalah tes lisan di mana tes ini digunakan untuk mengukur kemampuan siswa dalam membaca Al-Qur"en setelah menggunakan metode tilawati.

2. Dokumentasi, Margono mengemukakan, bahwa teknik dokumentasi adalah cara mengumpulkan data melalui peninggalan tertulis, seperti arsip-arsip dan lain-lain yang berhubungan dengan masalah penelitian ${ }^{16}$

3. Observasi adalah metode pengumpulan data yang digunakan untuk menghimpun data penelitian, data-data penelitian tersebut dapat diamati oleh peneliti atau data tersebut dihimpun melalui pengamatan peneliti melalui penggunaan panca indera ${ }^{17}$ Teknik pendukung ini digunakan dengan cara mengamati secara langsung dengan melihat video yang dikirim anak-anak, karena melihat kondisi di lapangan untuk mengetahui pelaksanaan penerapan metode tilawati terkendala.

Adapun Instrumen ini menggunakan tes dengan penilaian pada Keindahan, Kelancaran Konsisten irama dan Pitch kontrol yang dituangkan dalam lembar penilaian yang disiapkan oleh peneliti dan tim.

\section{Siklus Penelitian}

Penelitian Tindakan Kelas Daring yang menggunakan 2 siklus. Pra siklus terjadi pada saat pertemuan pertama sajian materi QS An-Nisa'/4 : 59 yang penulis sajikan juga secara daring. Dari temuan itu, peneliti bersama dengan teman sejawat melakukan penelitian tindakan kelas yang diprediksi bisa memenuhi tahapan perbaikan setelah melalui 2 siklus.

1. Siklus 1

15 Suharsimi Arikonto, 2006. Penelitian Tindakan Kelas. Jakarta: PT Bumi Aksara:150

16 Sudaryono, Margono Gaguk \& Rahayu Wardani. 2013. Pengembangan Instrumen Penelitian Pendidikan.

Yogyakarta:Graha Ilmu:158

${ }^{17}$ Suharsimi Arikunto, 2006. Penelitian Tindakan Kelas. Jakarta: PT Bumi Aksara: 134 
a) Perencanaan Adapun langkah-langkah perencanaan yang dilakukan dalam penelitian ini meliputi :

1) Permintaan izin dari Kepala SMKN 2 Balikpapan.

2) Mengadakan analisa untuk mengidentifikasi permasalahan yang perlu segera perbaiki. Tahap ini peneliti melakukan pemeriksaan terhadap jawaban siswa dalam LKPD yang dikerjakan siswa pada sesi pra siklus 1.

3) Membuat lembar kerja siswa 2 untuk proses pembelajaran dengan menggunakan metode daring. Bagaimana aktifitas siswa dan kinerja guru selama proses pembelajaran berlangsung yaitu:

(a) Menetapkan materi pelajaran dengan berpedoman pada siklus.

(b) Membuat RPP.

(c) Membuat LKPD untuk siswa.

(d) Menyiapkan bahan belajar dan materi.

b) Pelaksanaan Tindakan

Pelaksanaan tindakan pada prinsipnya merupakan realisasi dari suatu yang sudah direncanakan sebelumnya. Pelaksanaan adalah bentuk kegiatan atau tindakan yang dilakukan dari semua yang telah direncanakan dengan penelitian sebagai berikut:

1)Menyajikan materi melalui LMS Schoology

2)Meminta siswa mengikuti sajian belajar yg sudah guru sajikan

3) Siswa menyelesaikan sajian belajar yang ada pada LMS

4) Guru memeriksa sajian belajar yang sudah dikerjakan siswa

c) Tahap Pengamatan

Tahapan ini difokuskan pada pemberian skor terhadap sajian belajar yang mengandung aspek penilaian dengan model soal uraian yang terdapat dalam LKPD. Pengamatan terhadap jawaban siswa dalam LKPD sekaligus angket akan memetakan tingkat perkembangan kemampuan siswa dalam menyajikan jawaban yang diusahakan siswa. Apakah sudah memenuhi kemampuan menganalisa atau kah belum.

d) Refleksi

Refleksi adalah untuk mengkaji keseluruhan tindakan yang telah dilakukan berdasarkan data yang telah terkumpul dan kemudian melakukan evaluasi guna menyempurnakan tindakan berikutnya. Tahap-tahap refleksi adalah:

1)Menganalisis kekurangan yang ada pada siklus 1

2) Berdiskusi dengan teman sejawat terkait aspek perbaikan yang akan dilakukan pada siklus berikutnya.

3)Menetapkan rencana siklus kedua

2. Siklus 2
a) Perencanaan
b) Pelaksanaan tindakan
c) Tahap pengamatan dan penilaian angket
d) Refleksi
e) Kesimpulan dan rekomendasi 


\section{Teknik Analisa dan Pengujian Hipotesis}

1. Teknik analisa

Data yang terkumpul berupa jawaban siswa akan dianalisis dengan rubrik yang berisi 4 variabel. Variabel keindahan diberi score 30. Variabel kelancaran score 30. Variabel konsistensi Irama diberi score 30. Variabel Pitch kontrol diberi skore 10.

2. Pengujian hipotesis

Memastikan hasil penelitian sinkron dan menjawab tujuan penelitian tindakan kelas

\section{Hasil dan Pembahasan}

Penelitian ini dilakukan di SMKN 2 Balikpapan yang memiliki 5 Guru Pendidikan Agama Islam dan Budi Pekerti. Mereka sudah berstatus sebagai Aparatur Sipil Negara (ASN). Dua guru laki-laki dan 3 guru wanita. Sekolah yang berlokasi di lembah pelajar Jl. Gunung Samarinda III Balikpapan Utara memiliki peserta didik yang didominasi oleh wanita karena ditinjau dari aspek sejarahnya, SMKN 2 Balikpapan bukan berlatar belakang Sekolah Tehnik namun Sekolah Ekonomi. Sangat proporsional kemudian bila jumlah GPAI didalamnya lebih banyak wanita, agar dalam proses pembimbingan dapat mengedepankan unsur-unsur keibuan selain kebapakan. Terlebih lagi status ASN yang sudah dimiliki oleh GPAI dapat diasumsikan bahwa secara latar ekonomi relatif tidak mengalami kerisauan untuk berkomitmen membimbing siswa.

SMKN 2 Balikpapan menerapkan 5 hari belajar dan kegiatan belajar mengajar (KBM) dilaksanakan secara daring sejak Maret 2020 hingga laporan ini disusun tidak ada perubahan kebijakan. Mata pelajaran yang digunakan di SMKN 2 Balikpapan bisa dikategorikan menjadi 3 kelompok besar yaitu normatif, adaptif dan produktif kejuruan. Mapel pendidikan agama Islam masuk Kelompok normatif yang memiliki 3 jam pelajaran dalam satu pekan. Oleh karenanya, penyajian KBM yang model sinkron via vicon diputuskan dalam rapat manajemen hanya 1 kali dalam satu bulan. Bila beruntung, wali kelas dapat menjadwalkan sampai dua kali dalam sebulan. Dalam artian bila dalam satu hari dan kelas tertentu siswa hanya belajar 3 mata pelajaran, setelah dibagi 3 pekan, semua mapel sudah kebagian waktu vicon. Maka 1 pekan sisanya diberikan jadwal vicon kepada mapel yang berada dijadwal pertama/ pagi.

Kelas XI Otkp 3 dalam penelitian ini mendapat jadwal pelajaran PAI-BP setiap hari senin jam ke 7-9. Selain mapel PAI-BP, pada hari yang sama XI Otkp 3 memiliki jadwal mata pelajaran OTK Humas dan keprotokolan (6 jam), dan Teknologi Perkantoran (1 jam). Pembagian jam sebagaimana tersebut berlaku pada saat pembelajaran tatap muka di kelas. Sejak bermoda daring, semua mapel seragam hanya memberikan layanan belajar maksimal 1 jam perhari. Untuk hari senin di kelas XI Otkp 3 KBM daring secara berurutan menjadi sebagai berikut:

1. OTK Humas dan keprotokolan Pukul 07.45 s.d 10.45 wita

2. Istirahat Pukul 10.45 s.d 11.10 wita

3. Masih lanjut OTK Humas dan keprotokolan (2jam) Pukul 11.10 s.d 12.40 wita

4. Istirahat Pukul 12.40 s.d 13.06 wita

5. PAI-BP pukul 13.06 s.d 15.20 wita

6. Teknologi Perkantoran pukul 15.20 s.d 16.05 wita 
Rambu-rambu kegiatan belajar dari jadwal diatas yang ditetapkan oleh bagian kurikulum adalah:

1. Sajian belajar dalam satu hari dapat diselesaikan oleh siswa dibawah 60 menit untuk setiap mapel;

2. Sajian belajar tidak memberatkan siswa dalam artian, proses penyelesaiannya tidak memaksa siswa harus keluar rumah;

3. Sajian belajar yang berorientasi projek, waktu penyelesaiannya diberi rentang pekan atau tidak sekaligus dikumpul saat tugas diberikan. Rentang pekan yang dimaksud diberikan kelonggaran antara 2 sampai 3 pekan diselesaikan. Artinya, di pekan kedua dan tiga, tidak ada lagi tugas tambahan buat siswa.

Situasi kurikuler yang demikian berpengaruh terhadap rencana pembelajaran yang disusun guru. Penyederhanaan kurikulum hal yang tidak dapat diabaikan. Kedalaman materi pun dicarikan metode yang tepat agar sesuai dengan kondisi kurikuler yang ditetapkan sekolah. Wawancara kepada wakil kepala sekolah terkait skenario kurikuler yang ditetapkan SMKN 2 Balikpapan, Bapak H. Sukarni Chandra, S.Pd menjelaskan bahwa, vicon yang hanya dilaksanakan satu mata pelajaran sehari bertujuan agar orangtua siswa tidak terbebani dengan quota internet. Harapannya partisipasi siswa dalam KBM moda sinkron vicon dapat tinggi. Siswa dan orang tua tidak dapat beralasan di quota karena dinilai masih setara pengelurannya dengan uang saku harian pada saat kelas tatap muka dimana sehari rata-rata siswa membawa Rp 20.000,-. Jika demikian cukuplah sehari modal 2 giga melaksanakan kegiatan belajar daring dari rumah masing-masing. Rata-rata vicon pun menurut pengakuan siswa dalam satu jam menghabiskan quota sekitar 1,3 Giga.

Dari jadwal itu dapat disimpulkan bahwa selama satu bulan kesempatan vicon di kelas XI Otkp 3 untuk mapel PAI-BP hanya mendapat jatah satu kali. Jadwal vicon yang diberikan kepada mapel PAI-BP pada tanggal 25 Agustus 2020. Pra siklus permasalahan hambatan belajar siswa terungkap pada 11 Agustus 2020 saat KBM dilakukan dengan moda sinkron LMS. Siklus pertama dilaksanakan pada tanggal 18 Agustus 2020 menggunakan moda sinkron LMS. Siklus kedua dilakukan dengan moda sinkron via vicon pada tanggal 25 Agustus 2020.

Mapel PAI-BP menggunakan kurikulum 2013 dan KI-KD yang digunakan merujuk pada permendibud no 37 tahun 2018. Pegangan guru dan siswa menggunakan buku terbitan Kementerian Agama Tahun 2019. Sumber belajar mapel agama Islam di perpustakaan termasuk lengkap. Di bidang tafsir Al Quran ada karya Quraish Shihab yang berjudul Al Misbah. Di bidang hadis ada kitab terjemahan Fathul Bari karya Ibnu Hajar Al Asqalani yang merupakan sarah paling populer dari kitab hadis Shohih Bukhari. Pada bidang fiqih, di perpustakaan peneliti dapati terjemah kitab Fiqh Sunnah karya Sayid Sabiq. Di bidang sejarah ada karya terjemah milik Husain Haikal yang berjudul sejarah Muhammad. Referensi yang sudah standar meski sangat disayangkan tidak dapat diakses langsung oleh siswa karena KBM tidak berjalan di kelas namun secara jarak jauh menggunakan koneksi internet dan aplikasi manajemen sistem belajar.

\section{Data saat pra siklus}

Pra siklus yang peneliti maksudkan adalah kondisi dimana pertama kali kemampuan belajar siswa pada ranah psikomotorik di level membaca indah menunjukkan derajat yang rendah dan disimpulkan dalam fase refleksi setelah KBM sebagai hambatan belajar siswa 
yang tepat diambil tindakan perbaikan. Kondisi ini tidak terungkap sebelumnya karena fokus kegiatan belajar mengajar di masa pendemi 3 pekan pertama fokus pada aktifitas kontrak belajar dan mengukur kemampuan membaca Al Quran peserta didik.

Siswa kelas XI Otkp 3 mengawali karir sebagai pelajar SMKN 2 Balikpapan menurut kalender pendidikan pada Senin 12 Juli 2019. Kegiatan sekolah selama kurang lebih 2 tahun ini dilakukan secara daring. Pekan kedua mereka baru mendapatkan jadwal pelajaran dan fokus pada tindakan bergabung dengan berbagai aplikasi manajemen belajar daring yang digunakan oleh guru-guru SMKN 2 Balikpapan. Setidaknya ada 4 aplikasi yang digunakan oleh bapak ibu guru dalam pembelajaran daring yaitu, schoology, google class room, edmodo dan Whatsapp group. SMKN 2 Balikpapan tidak menggunakan satu aplikasi tersendiri yang berbayar. Setiap guru diberi kebebasan memilih dan menggunakan aplikasi yang paling familiar digunakan. Kondisi tersebut menstimulasi siswa untuk beradabtasi. Pekan ketiga, Siswa kelas XI Otkp 3 kemudian sudah mulai mengikuti kegiatan vicon satu mata pelajaran perhari. Yang pada intinya, pekan ketiga banyak fokus kegiatan pada penerimaan kontrak belajar dari setiap mata pelajaran.

Kontrak mata pelajaran yang berlangsung pada pekan ketiga fokus pada pembahasan berapa hari aktif yang akan diikuti siswa pada setiap mata pelajaran dalam satu semester. Selanjutnya disampaikan juga oleh setiap guru materi apa saja yang akan dipelajari selama satu semester. Siswa juga mendapat penjelasan metode pembelajaran yang digunakan guru, berapa kali penilaian harian yang akan diikuti, kapan ulangan akhir semester akan dilakukan, formula penugasan selama satu semester sampai pembobotan setiap unsur yang akan dijadikan nilai rapot baik dari aspek sikap, pengetahuan dan keterampilan.

Pra siklus terlaksana pada Senin, 11 Agustus 2020. Peneliti menyajikan pembelajaran secara daring dengan materi pokok, Al-Qur'an; Membaca indah QS. Al-Maidab : 48, An-Nisa': 59 dan At-Taubah : 105. Materi tersebut bermuara dari kompetensi dasar sebagaimana tabel berikut:

\begin{tabular}{|c|c|c|}
\hline $\mathrm{NO}$ & $\mathrm{KD}$ & IPK \\
\hline 1.1 & $\begin{array}{l}\text { Meyakini bahwa taat pada aturan, } \\
\text { kompetisi dalam kebaikan dan etos kerja } \\
\text { sebagai perintah agama }\end{array}$ & Idem \\
\hline 2.1 & $\begin{array}{l}\text { Menaati aturan, tanggung jawab, } \\
\text { berkompetisi dalam kebaikan dan kerja } \\
\text { keras sebagai implementasi dari } \\
\text { pemahaman } Q S \text {. Al-Maidah: } 48, \text { An-Nisa': } \\
59 \text { dan At-Taubab: } 105 \text {. }\end{array}$ & Idem \\
\hline \multirow[t]{3}{*}{3.1} & $\begin{array}{l}\text { Menganalisis makna QS. Al-Maidah: } 48 \text {, } \\
\text { An-Nisa: } 59 \text { dan At-Taubah: } 105 \text { tentang } \\
\text { taat pada aturan, kompetisi dalam kebaikan } \\
\text { dan etos kerja }\end{array}$ & $\begin{array}{l}\text { Membaca indah QS. Al-Maidah: 48, An-Nisa': } 59 \text { dan } \\
\text { At-Taubah: } 105 \text {. }\end{array}$ \\
\hline & & $\begin{array}{l}\text { Menyimak bacaan indah QS. Al-Maidah: 48, An-Nisa': } \\
59 \text { dan At-Taubah: } 105 \text {. }\end{array}$ \\
\hline & & $\begin{array}{l}\text { Menterjemahkan QS. Al-Maidah:48, An-Nisa': } 59 \text { dan } \\
\text { At-Taubah: } 105 .\end{array}$ \\
\hline 4.1 & $\begin{array}{l}\text { Membaca QS. Al-Maidah: 48, An-Nisa': } 59 \\
\text { dan At-Taubah : } 105 \text { sesuai dengan kaidah } \\
\text { tajwid dan makharijul huruf. }\end{array}$ & $\begin{array}{l}\text { Membaca indah QS. Al-Maidah: 48, An-Nisa': } 59 \text { dan } \\
\text { At-Taubah: } 105 \text {. }\end{array}$ \\
\hline
\end{tabular}


Berdasarkan hasil observasi aktivitas siswa dan pengamatan guru, aspek keterampilan pada kegiatan pembelajaran dan hasil belajar siswa ternyata siswa belum mempunyai acuan irama yang teratur dalam membaca QS Al-Maidah:48, An-Nisa':59 dan At-Taubah:105 ini terbukti dari 21 siswa yang mengikuti video converence hanya 5 siswa yang bacaan Alqur'annya bernada dan sesuai hukum tajwid dan mencapai KKM yaitu untuk kelas XI disemester ganjil adalah 73. Banyaknya siswa yang kemampuan membaca $\mathrm{Al}$-qur'an rendah maka penulis lakukan perbaikan dan ini kami kategorikan sebagai siklus 1. Refleksi pra siklus ini adalah dalam pembelajaran peserta didik perlu dikenalkan bagaimana membaca indah dengan metode tilawati supaya bacaan Al-qur'an nya menjadi berlagu dan tartil. Oleh karena itu masih perlu dicontohkan cara membaca dengan penerapan tajwid yang tepat agar lebih bagus lagi bacaannya

\section{Data pada Siklus 1}

Siklus 1 berlangsung pada senin, 18 Agustus 2020. Tindakan yang dilakukan pada siklus ini meliputi perencanaan, pelaksanaan, observasi dan refleksi. Rinciannya sebagai berikut :

a. Perencanaan

Kegiatan perencanaan yang sudah dilakukan menyusun rencana pelaksanaan pembelajaran (RPP) untuk KBM daring selama 60 menit. Materi pokok untuk siklus 1 masih materi tentang QS Al-Maidah:48, An-Nisa':59 dan At-Taubah:105, IPK pada siklus 1 adalah : Menganalisis hukum tajwid QS Al-Maidah:48, An-Nisa':59 dan AtTaubah:105. IPK ini menjadi bahan pertimbangan karena dalam membaca indah Alqur'an harus mengetahui hukum tajwid

b. Pelaksanaan

Pelaksanaan pembelajaran pada siklus 1 tersusun melalui langkah-langkah sebagai berikut:

- Guru mendemonstrasikan bacaan indah QS Al-Maidah:48, An-Nisa':59 dan AtTaubah:105

- Siswa menyimak dan mengikuti bacaan mendemonstrasikan secara berulang-ulang QS Al-Maidah:48, An-Nisa':59 dan At-Taubah:105

- Siswa bergantian mempresentasikan hasil diskusi hukum tajwid QS Al-Maidah:48, An-Nisa':59 dan At-Taubah:105

Dari hasil siklus 1 dapat dilihat kemampuan membaca indah QS Al-Maidah:48, An-Nisa':59 dan At-Taubah:105 naik secara signifikan, tetapi karena masih ada 10 siswa yang belum mencapai KKM, maka kami melakukan tindakan perbaikan pada siklus 2 .

\section{Data pada siklus 2}

a. Perencanaan

Pada perencanaan kegiatan ini peneliti melakukan kegiatan sebagai berikut :

1) Menentukan materi pembelajaran

2) Membuat Rencana Pelaksanaan Pembelajaran (RPP)

3) Membuat alat evaluasi (instrumen)

b. Pelaksanaan

Pada siklus 2 ini guru mengawali kegiatan belajar dengan cara memotivasi siswa melalui penyampaian pentingnya membaca Al-qur'an dengan tartil sesuai makhorijul huruf. Kegiatan inti pembelajaran lebih diarahkan pada upaya untuk memperbaiki kegiatan 
paga siklus 1 dengan cara guru memberika contoh bacaan yang sesuai dengan makhraj dan tajwid (qalqalah dan gunnah) yang benar menggunakan irama Tilawati. Setelah itu siswa mengulang-ulang bacaan surah tersebut sesuai arahan guru. Dari hasi pengamatan pada siklus 2 tidak ada siswa yanga belum tuntas, sedangkan siswa yang mencapai ketuntasan sebanyak 21 siswa atau $100 \%$.

Dengan demikian ditinjau dari sudut ketuntasan telah terjadi peningkatan dari 52, 38\% menjadi 100\%. Kemudian berdasarkan penilaian hasil tugas pada siklus 2 ratarata 82 , sehingga dapat diartikan bahwa penggunaan metode Tilawati dalam membaca indah QS Al-Maidah:48, QS An-Nisa':59 dan QS At-Taubah:105 dalam pembelajaran sudah ada peningkatan.

c. Refleksi

Berdasarkan hasil pengamatan pada kegiatan belajar mengajar melalui tes keterampilan membaca indah QS Al-Maidah:48, QS An-Nisa':59 dan QS At-Taubah:105 menunjukkan peningkatan keberhasilan. Hal ini terbukti pada pembelajaran siklus 2 siswa yang berpartisipasi aktif dalam pembelajaran mencapai 100\%. Dengan persentasi siswa yang tuntas mencapai kriteria Ketuntasan Minimal mencapai 73\%.

\section{Analisis data}

Penggunaan metode Tilawati pada materi QS Al-Maidah;48, An-Nisa':59 dan AtTaubah:105 dilaksanakan pada tahap pembelajaran dalam siklus 1 dengan metode demonstrasi dan siklus 2 dengan metode menyimak irama terbimbing Tilawati. Dalam pembelajaran membaca QSAl-Maidah;48, An-Nisa':59 dan At-Taubah:105 menggunakan metode Tilawati ini peserta didik semakin baik membaca indahnya karena mudah dan menyenangkan, mereka merespon materi dengan baik sesuai tujuan pembelajaran.

Berdasarkan data dari siklus 1 hingga siklus 2 terdapat peningkatan kemampuan ketrampilan membaca indah pada materi QS Al-Maidah;48, An-Nisa'59 dan At-Taubah:105 dimana pada kondisi siklus 1 rata-rata nilai keterampilan mencapai 70 sedangkan siklus 2 kisaran 82 yang mana telah mencapai tingkat ketuntasan diatas $73 \%$ dari 21 siswa yaitu dengan KKM yeng telah ditetepkan yaitu 73.

Rekapitulasi perolehan rata-rata nilai keterampilan siklus 1 dan 2

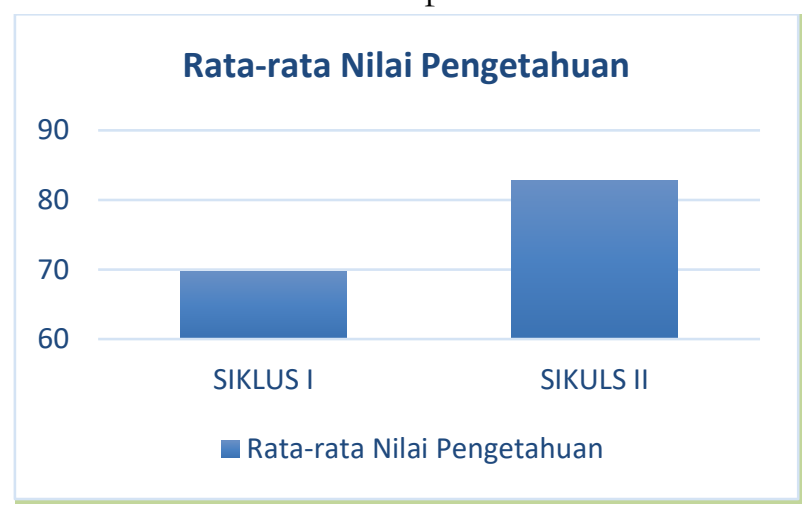

Hal ini menunjukkan bahwa dari siklus 1 dan 2 ketuntasan dalam membaca Al-qur'an meningkat. Dari hasil tersebut dapat disimpulkan bahwa dengan menggunakan metode Tilawati dapat meningkatkan kemampuan membaca indah QS Al-Maidah;48, An-Nisa':59 dan At-Taubah:105 tentang kompetisi dalam kebaikan, taat aturan dan etos kerja. 


\section{Kesimpulan}

Keberhasilan strategi pembelajaran Al-qur'an menggunakan metode Tilawati sebagai upaya untuk meningkatkan kemampuan membaca indah peserta didik kelas XI Otkp 3 di SMK Negeri 2 Balikpapan, ditunjukkan dengan adanya perubahan peningkatan dalam proses pembelajaran yaitu kesiapan dan keaktifan pada saat proses pembelajaran Al-qur'an, juga ditunjukkan adanya peningkatan nilai skor tes akhir dari masing-masing siklus.

Hal ini dapat dilihat dari perolehan skor yang dipresentasikan melalui pengamatan tentang semangat belajar peserta didik dengan kesiapan dan keaktifan dalam proses pembelajaran. Berdasarkan siklus 1 dan 2, terdapat peningkatan kemampuan membaca indah pada materi QS AlMaidah;48, An-Nisa':59 dan At-Taubah:105 oleh siswa kelas XI Otkp 3 di SMK Negeri 2 Balikpapan.

Dimana pada siklus 1 rata-rata nilai keterampilan membaca indah dicapai pada kisaran 69,95 sedangkan pada siklus 2 rata-rata nilai keterampilan membaca indah menggunakan metode Tilawati berada pada kisaran mencapai 82,38. Dimana telah mencapai pada tingkat ketuntasan diatas 73\% dari siswa yang berjmlah 21 yaitu dengan KKM yang telah ditentukan adalah 73 .

Dengan meningkatnya kemampuan membaca indah pada materi QS Al-Maidah;48, An-Nisa':59 dan At-Taubah:105 yang mempunyai dampak positif yaitu peningkatan nilai skor akhir diatas nilai ketuntasan minimal KKM (73) kemampuan membaca maka pembelajaran Al-qur'an menggunakan metode Tilawati berjalan efektif diterapkan dalam pembelajaran PAI.

Dalam pembahasan- pembahasan PTK ini tentunya tidak luput dari kekurangan dan ketidaksempurnaan. Hal ini dikarenakan keterbatasan pengetahuan dan kemampuan yang penulis miliki. Saran-saran yang penulis ungkapkan diharapkan menjadi koreksi dan bagian pertimbangan bagi semua guru di Negara Kesatuan Republik Indonesia. Peneliti berharap semoga PTK yang sederhana ini bermanfaat bagi peulis khususnya dan bagi para pembaca pada umumnya 


\section{Daftar Pustaka}

Fakultas Tarbiyah IAIN Walisongo. 1999. Metodologi Pengajaran Agama.

Yogyakarta: Pustaka Pelajar Offset.

Kamus Besar Bahasa Indonesia (KBBI). 2008. Jakarta: Pusat Bahasa.

Saefullah, U. 2012. Psikologi Perkembangan dan Pendidikan. Bandung: CV Pustaka Setia.

Suprijono, Agus. 2009. Cooperative Learning. Yogyakarta: Pustaka Pelajar.

Majid, Abdul. 2012. Belajar dan Pembelajaran Pendidikan Agama Islam.

Bandung: PT. Remaja Rosdakarya.

Munjahid. 2007. Strategi Menghafal Al-Qur'an 10 Bulan Khatam. Yogyakarta:

IDEA Press.

Arikunto, Suharsimi. 2006. Penelitian Tindakan Kelas. Jakarta: PT Bumi Aksara.

Sudaryono, Margono Gaguk \& Rahayu Wardani. 2013. Pengembangan Instrumen

Penelitian Pendidikan. Yogyakarta:Graha Ilmu.

Furchan, Arief. 2004. Pengantar Penelitian dalam Pendidikan. Yogyakarta:

Pustaka Pelajar.

Gulo, W. 2010. Metodologi Penelitian. Jakarta: Gramedia Widiasarana Indonesia.

Izzan, Ahmad. 2013. Ulumul Qur'an: Telaah Tekstualitas dan Kontekstualitas

Al-Qu'ran. Bandung: Tafakur.

Majid, Abdul. 2012. Belajar dan Pembelajaran Pendidikan Agama Islam.

Bandung: PT. Remaja Rosdakarya.

Munjahid. 2007. Strategi Menghafal Al-Qur'an 10 Bulan Khatam. Yogyakarta:

IDEA Press.

Munir, Ahmad Sudarsono. 1994. Ilmu Tajwid dan Seni Baca Al-Qur'an. Jakarta:

PT Rineka Cipta.

Prasetyono, Dwi Sunar. 2008. Rahasia Mengajarkan Gemar Membaca pada Anak Sejak Dini. Jogjakarta: Think.

Belajar-Mengajar Pendidikan Agama Islam. Yogyakarta: Pustaka Pelajar.

Zawawie, Mukhlishoh. 2011. Pedoman Membaca, Mendengar, dan Menghafal Al-Qur'an. Solo:

Tinta Medina. 